\title{
Concentrations of iodine-129 in coastal surface sediments around spent nuclear fuel reprocessing plant at Rokkasho, Japan, during and after its test operation
}

\author{
Yuhi Satoh $^{1} \cdot$ Shinji Ueda $^{1} \cdot$ Hideki Kakiuchi $^{1} \cdot$ Yoshihito Ohtsuka $^{1} \cdot$ Shun'ichi Hisamatsu $^{2}$
}

Received: 27 August 2019 / Published online: 4 November 2019

(c) The Author(s) 2019

\begin{abstract}
Concentrations of ${ }^{129} \mathrm{I}$ in coastal surface sediment samples from the east coast of Aomori, Japan, 2-65 km away from the wastewater outlet of the nuclear fuel reprocessing plant at Rokkasho, Japan, were measured from 2006 to 2010 . No clear effect on ${ }^{129} \mathrm{I} /{ }^{127} \mathrm{I}$ atom ratios in marine sediments was observed, although ${ }^{129} \mathrm{I}$ was discharged from the plant, during its test operation using actual spent fuel, mainly between 2006 and 2008. The ratio in sediments collected at a fishing port at the mouth of a brackish lake increased in 2007 , showing that the ${ }^{129}$ I migrated from the lake to the port.
\end{abstract}

Keywords Iodine-129 - Aquatic sediment $\cdot$ Spent nuclear fuel reprocessing plant $\cdot$ Rokkasho

\section{Introduction}

Iodine-129 is one of the major radionuclides released to the atmosphere and aquatic environments from spent nuclear fuel reprocessing plants during their normal operation $[1,2]$. Since ${ }^{129} \mathrm{I}$ has a long half-life of $1.57 \times 10^{7}$ years, the environmental behavior of ${ }^{129} \mathrm{I}$ should be studied to ensure the safety of the local population around the reprocessing plant and also for public acceptance of such plants. Additionally, ${ }^{129}$ I has become an indicator estimating behaviors of other anthropogenic radionuclides, such as ${ }^{131} \mathrm{I}$, in coastal areas [3-5]. Therefore, it is important to understand the dynamics of ${ }^{129} \mathrm{I}$ in aquatic environments.

Japan Nuclear Fuel Limited (JNFL) constructed the first large commercial spent nuclear fuel reprocessing plant in Rokkasho, Aomori, northeast Japan. The plant is under final

Electronic supplementary material The online version of this article (https://doi.org/10.1007/s10967-019-06887-x) contains supplementary material, which is available to authorized users.

Yuhi Satoh

satoh.yuhi@ies.or.jp

1 Department of Radioecology, Institute for Environmental Sciences (IES), 1-7 Ienomae, Rokkasho, Aomori 039-3212, Japan

2 Institute for Environmental Sciences (IES), 1-7 Ienomae, Rokkasho, Aomori 039-3212, Japan safety review of its operation by the Nuclear Regulation Authority. Before the start of the review, JNFL tested the plant performance by processing actual spent nuclear fuel from the end of March 2006. The spent fuel rods were cut and dissolved during the period from April 2006 to October 2008 (hereafter referred to as the "cutting period"). During the cutting period, 0.74 and $0.50 \mathrm{GBq}$ of ${ }^{129} \mathrm{I}$ were discharged from the main stack of the plant to the atmosphere and from a wastewater pipeline outlet to the Pacific Ocean (JFNL, http://www.jnfl.co.jp/safety-agreement, Fig. S1). Since October 2008, no significant discharge of ${ }^{129}$ I has been reported, except for occasional low-level discharges.

The reprocessing plant is located in a coastal area in northeast Japan, bordering the Pacific Ocean (Fig. 1). The plant is situated adjacent to a brackish lake, Lake Obuchi, which has a fishing port at its mouth to the Pacific Ocean. The wastewater from the plant has discharged from a pipeline outlet ca. $2.5 \mathrm{~km}$ offshore from the port. We have measured ${ }^{129}$ I concentrations in various aquatic environmental samples collected around the plant and have already reported part of these data. In brackish Lake Obuchi, the ${ }^{129}$ I concentrations in the lake water increased significantly during the cutting period and thereafter decreased almost to background levels within a few years [6]. The concentrations of ${ }^{129} \mathrm{I}$ in aquatic organisms in the lake, such as seagrass, fish, shellfish, and shrimp, also increased during the cutting period, followed by a rapid decrease [7]. The ${ }^{129} \mathrm{I} /{ }^{127} \mathrm{I}$ atom ratios in the latter samples were found to depend on the ratio 


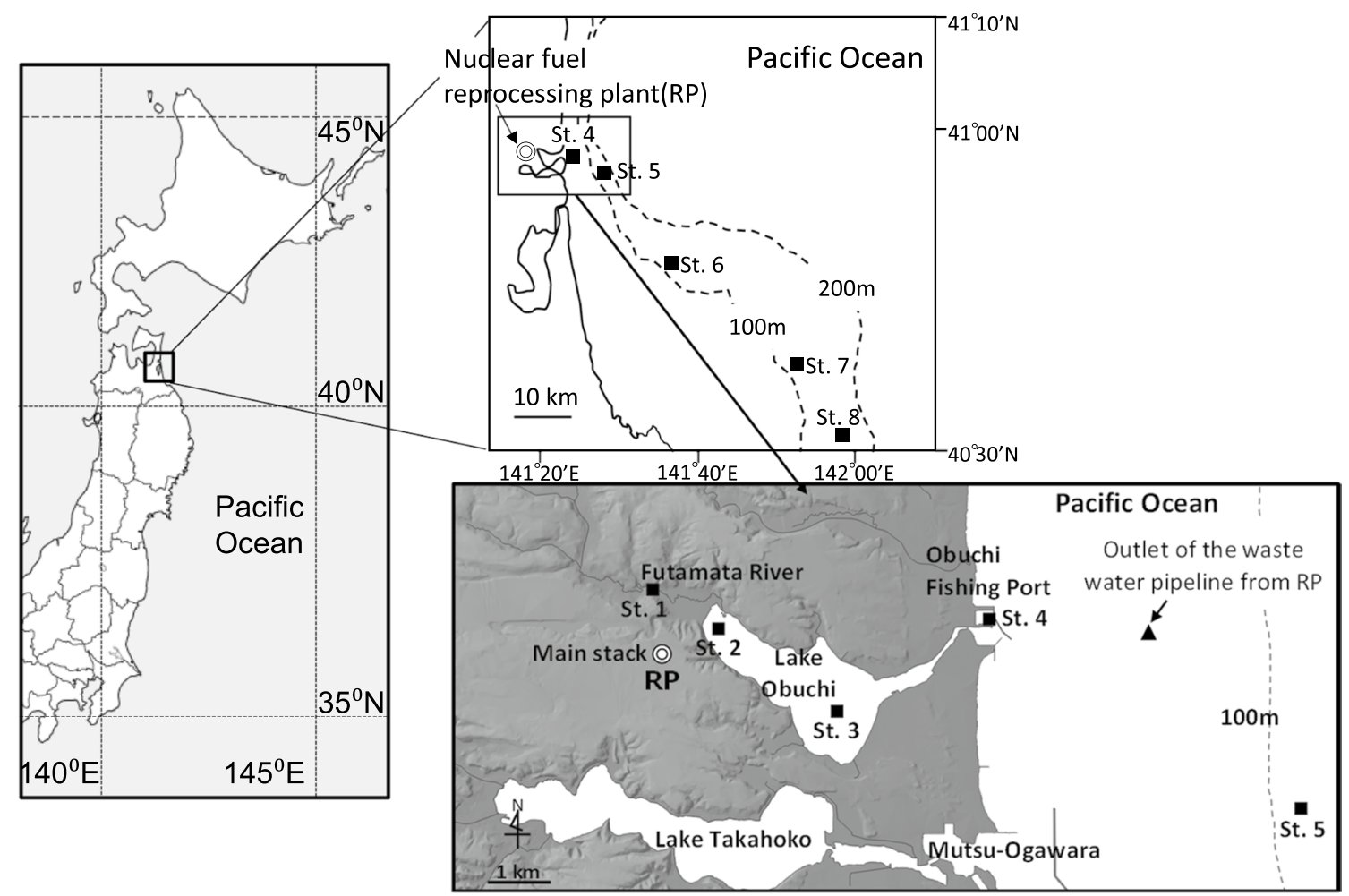

Fig. 1 Sampling sites in Aomori, east coast of Japan. Black squares are sampling stations. Station numbers 1 to 3 have been sampled and reported in previous studies [8]. A double circle and triangle repre-

in the lake water. On the other hand, the ${ }^{129} \mathrm{I}$ inventory in the lake sediment increased during the cutting period and this level persisted after that period, suggesting an equilibrium between ${ }^{129} \mathrm{I}$ deposition on the sediment and dissolution from it or strong fixing of ${ }^{129} \mathrm{I}$ to the sediment [8].

We also measured ${ }^{129}$ I concentrations in seawater samples collected near the outlet of the wastewater pipeline and reported a slight increasing tendency during the cutting period [6]. The ${ }^{129}$ I discharged from the plant is also considered to affect its level in coastal marine sediments, such as in the case of lake sediment in the Obuchi Lake. To clarify the effect of the discharged ${ }^{129} \mathrm{I}$ to the concentration levels in the marine sediments, we measured ${ }^{129}$ I concentrations in marine sediment samples collected from the coastal sea area, including the Rokkasho coast.

\section{Experimental}

\section{Sampling}

The surface $(0-5 \mathrm{~cm})$ sediment samples were collected from the five stations shown in Fig. 1 using the Smith-McIntyre grab sampler (Smith-Mcintyre Bottom Sampler 5144-B, Rigo Co. Ltd., Japan) once per year during 2006 to 2010 sent the nuclear fuel reprocessing plant and its emissions pipeline outlet, respectively. The dotted lines represent bathymetric contours with water depths

(Table 1). The sediment samples at all stations were sandy except for St. 4 at Obuchi Fishing Port, where it was somewhat muddy. Since the southward ocean current is the most dominant in the Rokkasho coast [9], the sampling stations were located along the coastal area south from the wastewater pipeline outlet of the reprocessing plant. St. 4 is located inside the breakwater of the port facing the mouth of the channel from Lake Obuchi to the Pacific Ocean. The collected samples were dried at $80{ }^{\circ} \mathrm{C}$ for 24 to $48 \mathrm{~h}$ and sieved by a $2 \mathrm{~mm}$ mesh to remove large particles, such as seashells and gravel.

\section{Analysis}

The detailed analytical procedure of ${ }^{129} \mathrm{I}$ has been reported in the previous study [8]. Briefly, the dried sample was combusted under a flow of oxygen in a quartz tube placed in a muffle furnace after addition of an iodine carrier (Woodward Iodine Co., USA), trapping the iodine volatilized by the combustion in tetramethyl-ammonium hydroxide (TMAH) solution. The iodine in the solution was purified by toluene extraction with oxidation-reduction of iodine, followed by precipitation as AgI. The ${ }^{129} \mathrm{I} /{ }^{127} \mathrm{I}$ atom ratio in the AgI sample was determined with an accelerator mass spectrometer (AMS) at the PRIME Laboratory of Purdue University, 
Table 1 Concentration of ${ }^{129} \mathrm{I},{ }^{137} \mathrm{Cs}$, organic carbon, and ${ }^{129} \mathrm{I} /{ }^{127} \mathrm{I}$ atom ratio in coastal sediments collected from Rokkasho coast, Japan

\begin{tabular}{|c|c|c|c|c|c|c|c|c|}
\hline Station & $\begin{array}{l}\text { Sampling date } \\
\text { (year/month/ } \\
\text { day) }\end{array}$ & $\begin{array}{l}{ }^{129} \mathrm{I}_{\text {concentra- }} \\
\text { tion }\left(\mathrm{Bq} \mathrm{g}^{-1}\right. \\
\mathrm{DW})\end{array}$ & Error $^{\mathrm{a}}$ & ${ }^{129} \mathrm{I} /{ }^{127} \mathrm{I}$ atom ratio & Error $^{b}$ & $\begin{array}{l}{ }^{137} \mathrm{Cs}_{\text {concentra- }} \\
\text { tion }\left(\mathrm{Bq} \mathrm{g}^{-1}\right. \\
\mathrm{DW})\end{array}$ & Error $^{\mathrm{a}}$ & $\begin{array}{l}\text { Organic carbon } \\
\text { concentration }\left(\mathrm{mg}^{-1}\right. \\
\text { DW) }\end{array}$ \\
\hline St. 4 & $2006 / 6 / 28$ & $1.4 \mathrm{E}-8^{\mathrm{c}}$ & $5.6 \mathrm{E}-10$ & $1.4 \mathrm{E}-10$ & $5.7 \mathrm{E}-12$ & $5.9 \mathrm{E}-4$ & $9.0 \mathrm{E}-5$ & 4.5 \\
\hline $40^{\circ} 57.94^{\prime} \mathrm{N}$ & $2007 / 6 / 27$ & $9.1 \mathrm{E}-8$ & $4.2 \mathrm{E}-9$ & $5.2 \mathrm{E}-10$ & $2.7 \mathrm{E}-11$ & $7.6 \mathrm{E}-4$ & $7.0 \mathrm{E}-5$ & 8.9 \\
\hline $141^{\circ} 23.43^{\prime} \mathrm{E}$ & $2008 / 6 / 16$ & $1.7 \mathrm{E}-7$ & $1.6 \mathrm{E}-8$ & $1.0 \mathrm{E}-09$ & $9.6 \mathrm{E}-11$ & $4.8 \mathrm{E}-4$ & $1.1 \mathrm{E}-4$ & 8.1 \\
\hline \multirow[t]{2}{*}{ Depth: $4 \mathrm{~m}$} & $2009 / 6 / 25$ & $1.6 \mathrm{E}-7$ & $3.7 \mathrm{E}-9$ & $9.3 \mathrm{E}-10$ & $2.1 \mathrm{E}-11$ & $7.4 \mathrm{E}-4$ & $1.3 \mathrm{E}-4$ & 7.2 \\
\hline & $2010 / 6 / 22$ & $9.2 \mathrm{E}-8$ & $4.1 \mathrm{E}-9$ & $1.2 \mathrm{E}-09$ & $5.2 \mathrm{E}-11$ & $4.6 \mathrm{E}-4$ & $7.8 \mathrm{E}-5$ & 4.4 \\
\hline St. 5 & $2006 / 6 / 28$ & $2.4 \mathrm{E}-8$ & $1.1 \mathrm{E}-9$ & $1.2 \mathrm{E}-10$ & $5.7 \mathrm{E}-12$ & $9.2 \mathrm{E}-4$ & $7.0 \mathrm{E}-5$ & 1.9 \\
\hline $40^{\circ} 56.38^{\prime} \mathrm{N}$ & $2007 / 6 / 27$ & $1.8 \mathrm{E}-8$ & $7.6 \mathrm{E}-10$ & $1.6 \mathrm{E}-10$ & $7.1 \mathrm{E}-12$ & $9.1 \mathrm{E}-4$ & $8.0 \mathrm{E}-5$ & 0.7 \\
\hline $141^{\circ} 27.43^{\prime} \mathrm{E}$ & $2008 / 6 / 16$ & $2.2 \mathrm{E}-8$ & $1.5 \mathrm{E}-9$ & $1.9 \mathrm{E}-10$ & $1.3 \mathrm{E}-11$ & $8.7 \mathrm{E}-4$ & $5.0 \mathrm{E}-5$ & 0.8 \\
\hline \multirow[t]{2}{*}{ Depth: $120 \mathrm{~m}$} & $2009 / 6 / 25$ & $1.2 \mathrm{E}-8$ & $3.5 \mathrm{E}-10$ & $9.8 \mathrm{E}-11$ & $3.2 \mathrm{E}-12$ & $9.5 \mathrm{E}-4$ & $1.2 \mathrm{E}-4$ & 1.3 \\
\hline & $2010 / 6 / 22$ & $1.7 \mathrm{E}-8$ & $2.0 \mathrm{E}-9$ & $1.5 \mathrm{E}-10$ & $1.8 \mathrm{E}-11$ & $8.6 \mathrm{E}-4$ & $1.0 \mathrm{E}-4$ & 1.4 \\
\hline St. 6 & $2006 / 6 / 27$ & $1.7 \mathrm{E}-8$ & $6.3 \mathrm{E}-10$ & $9.2 \mathrm{E}-11$ & $3.5 \mathrm{E}-12$ & $9.5 \mathrm{E}-4$ & $7.0 \mathrm{E}-5$ & 1.1 \\
\hline $40^{\circ} 48.58^{\prime} \mathrm{N}$ & $2007 / 6 / 26$ & $2.3 \mathrm{E}-8$ & $7.7 \mathrm{E}-10$ & $2.0 \mathrm{E}-10$ & $7.2 \mathrm{E}-12$ & $7.7 \mathrm{E}-4$ & $1.0 \mathrm{E}-4$ & 0.5 \\
\hline $141^{\circ} 32.91^{\prime} \mathrm{E}$ & $2008 / 6 / 17$ & $2.6 \mathrm{E}-8$ & $1.8 \mathrm{E}-9$ & $1.9 \mathrm{E}-10$ & $1.3 \mathrm{E}-11$ & $8.2 \mathrm{E}-4$ & $1.1 \mathrm{E}-4$ & 1.1 \\
\hline \multirow[t]{2}{*}{ Depth: $95 \mathrm{~m}$} & $2009 / 6 / 24$ & $1.8 \mathrm{E}-8$ & $5.5 \mathrm{E}-10$ & $1.6 \mathrm{E}-10$ & $5.0 \mathrm{E}-12$ & $8.7 \mathrm{E}-4$ & $8.8 \mathrm{E}-5$ & 1.4 \\
\hline & $2010 / 6 / 29$ & $1.8 \mathrm{E}-8$ & $7.5 \mathrm{E}-10$ & $1.5 \mathrm{E}-10$ & $6.5 \mathrm{E}-12$ & $8.8 \mathrm{E}-4$ & $9.1 \mathrm{E}-5$ & 1.5 \\
\hline St. 7 & $2006 / 6 / 26$ & $2.2 \mathrm{E}-8$ & $9.6 \mathrm{E}-10$ & $1.9 \mathrm{E}-10$ & $8.6 \mathrm{E}-12$ & $6.2 \mathrm{E}-4$ & $5.0 \mathrm{E}-5$ & 0.9 \\
\hline $40^{\circ} 39.83^{\prime} \mathrm{N}$ & $2007 / 6 / 26$ & $1.4 \mathrm{E}-8$ & $6.9 \mathrm{E}-10$ & $1.6 \mathrm{E}-10$ & $9.2 \mathrm{E}-12$ & $4.7 \mathrm{E}-4$ & $6.0 \mathrm{E}-5$ & 0.2 \\
\hline $141^{\circ} 48.03^{\prime} \mathrm{E}$ & $2008 / 6 / 18$ & $1.2 \mathrm{E}-8$ & $1.7 \mathrm{E}-9$ & $1.4 \mathrm{E}-10$ & $1.9 \mathrm{E}-11$ & $6.8 \mathrm{E}-4$ & $8.0 \mathrm{E}-5$ & 0.6 \\
\hline \multirow[t]{2}{*}{ Depth: 95 m } & $2009 / 6 / 24$ & $2.3 \mathrm{E}-8$ & $7.2 \mathrm{E}-10$ & $1.9 \mathrm{E}-10$ & $7.9 \mathrm{E}-12$ & $6.5 \mathrm{E}-4$ & $4.8 \mathrm{E}-5$ & 1.0 \\
\hline & $2010 / 6 / 29$ & $2.9 \mathrm{E}-8$ & $2.7 \mathrm{E}-9$ & $1.7 \mathrm{E}-10$ & $4.2 \mathrm{E}-12$ & $5.6 \mathrm{E}-4$ & $8.1 \mathrm{E}-5$ & 1.9 \\
\hline St. 8 & $2006 / 6 / 26$ & $3.6 \mathrm{E}-8$ & $1.5 \mathrm{E}-9$ & $1.8 \mathrm{E}-10$ & $7.7 \mathrm{E}-12$ & $5.4 \mathrm{E}-4$ & $5.0 \mathrm{E}-5$ & 1.9 \\
\hline $40^{\circ} 32.95^{\prime} \mathrm{N}$ & $2007 / 6 / 26$ & $3.9 \mathrm{E}-8$ & $1.8 \mathrm{E}-9$ & $1.5 \mathrm{E}-10$ & $7.0 \mathrm{E}-12$ & $9.1 \mathrm{E}-4$ & $1.0 \mathrm{E}-4$ & 2.4 \\
\hline $141^{\circ} 57.42^{\prime} \mathrm{E}$ & $2008 / 6 / 19$ & $3.8 \mathrm{E}-8$ & $5.6 \mathrm{E}-9$ & $1.4 \mathrm{E}-10$ & $2.0 \mathrm{E}-11$ & $9.1 \mathrm{E}-4$ & $4.0 \mathrm{E}-5$ & 2.6 \\
\hline \multirow[t]{2}{*}{ Depth: $120 \mathrm{~m}$} & $2009 / 6 / 24$ & $4.4 \mathrm{E}-8$ & $1.4 \mathrm{E}-9$ & $9.7 \mathrm{E}-11$ & $3.9 \mathrm{E}-12$ & $6.3 \mathrm{E}-4$ & $8.5 \mathrm{E}-5$ & 3.3 \\
\hline & $2010 / 6 / 29$ & $2.5 \mathrm{E}-8$ & $9.7 \mathrm{E}-10$ & $1.0 \mathrm{E}-10$ & $4.2 \mathrm{E}-12$ & $6.1 \mathrm{E}-4$ & $6.4 \mathrm{E}-5$ & 2.5 \\
\hline
\end{tabular}

The concentration of ${ }^{137} \mathrm{Cs}$ was calculated decay-corrected to an initial value at each sampling time

${ }^{a}$ Counting statistics error (a standard deviation)

${ }^{b}$ Error propagated from counting statistics of ${ }^{129} \mathrm{I}$ and a standard deviation of repeated scan results for ${ }^{127} \mathrm{I}$ by the ICP-MS

${ }^{\mathrm{c}}$ The number of significant digits for the data in this table is two

USA. To determine the ${ }^{129} \mathrm{I}$ concentration, the ${ }^{127}$ I concentration in the sample was measured using an inductively coupled plasma mass spectrometer (Agilent-7700, Agilent Technologies, Inc., USA) after extraction of iodine with TMAH solution. A standard reference material (IAEA-375, soil sample) with the reference value of $1.7 \mathrm{mBq} \mathrm{kg}^{-1}$-dry weight (DW) of ${ }^{129}$ I concentration was also analyzed to maintain high accuracy of the measured results.

The organic carbon (OC) concentration in the sample was measured using an elemental analyzer (NCS-2500, CE Instruments, Italy) after removing the inorganic carbon by $\mathrm{HCl}$.

The concentration of ${ }^{137} \mathrm{Cs}$ in the samples, which were packed into plastic containers $(60 \mathrm{~mm}$ diameter and $37 \mathrm{~mm}$ height) was analyzed using high-purity Ge semiconductor detectors (relative efficiencies of $25 \%$ and $59 \%$, Seiko EG \& G Ortec, USA) connected to multi-channel analyzers. The counting efficiency of each detector was determined using a set of standard radioactive volume sources in the same sized containers (MX033U8PP, Japan Radioisotope Association, Japan). Counting time was approximately 150,000 to $340,000 \mathrm{~s}$ for a sample with 90 to $160 \mathrm{~g}$-DW. The concentration of ${ }^{137} \mathrm{Cs}$ was decay-corrected to that at each sampling time.

\section{Results and discussion}

The ${ }^{129} \mathrm{I}$ concentrations and ${ }^{129} \mathrm{I} /{ }^{127} \mathrm{I}$ atom ratios in the sediment samples are shown in Fig. 2 and Table 1. A clear increase in the ${ }^{129} \mathrm{I}$ concentrations during the cutting period (2006-2008) was observed only at St. 4 at Obuchi Fishing Port by the mouth of Lake Obuchi, while no significant temporal trend was found for the offshore marine 


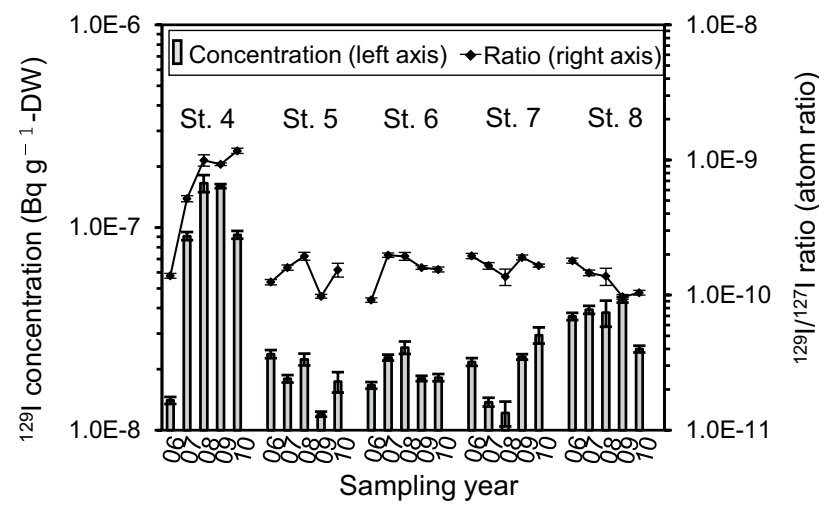

Fig. $2{ }^{129} \mathrm{I}$ concentrations and ${ }^{129} \mathrm{I} /{ }^{127} \mathrm{I}$ atom ratios in coastal sediment samples. The bars represent measurement errors described in Table 1

sediment samples at St's. 5-8. In particular, the ${ }^{129} \mathrm{I} /{ }^{127} \mathrm{I}$ atom ratios of the offshore samples had a rather small CV of less than $30 \%$ at each station with the overall mean and a standard deviation of $[1.5 \pm 0.3] \times 10^{-10}$. Since we have no background data for coastal marine sediments in the target sea area before the cutting period, a direct comparison between the present data and background values is not possible.

The ${ }^{129} \mathrm{I} /{ }^{127} \mathrm{I}$ atom ratio of $1.2 \times 10^{-10}$ was measured in the sediment sample from St. 5 on 28 June 2006, which was closest to the wastewater pipeline outlet. No liquid ${ }^{129}$ I discharge from the plant was reported until August 2006, although ${ }^{129}$ I had been discharged atmospherically from April 2006 (Fig. S1). The mean ${ }^{129} \mathrm{I} /{ }^{127} \mathrm{I}$ atom ratio during 2006 to 2010 was $[1.4 \pm 0.4] \times 10^{-10}$ for sediment samples at St. 5, and the trend of the ratio appeared to be unaffected by ${ }^{129} \mathrm{I}$ discharged from the plant during the cutting period (2006-2008). Similar values of the ${ }^{129} \mathrm{I} /{ }^{127} \mathrm{I}$ atom ratio recorded at other stations (St. 6 to St. 8) with those at St. 5 also support the lack of an effect from the discharged ${ }^{129}$ I on the sediments; no obvious dilution effect of ${ }^{129} \mathrm{I}$ with distance from the wastewater pipeline outlet was found. Overall, it is difficult to conclude that the discharged ${ }^{129} \mathrm{I}$ affected the measured ${ }^{129} \mathrm{I} /{ }^{127} \mathrm{I}$ atom ratio in the costal marine sediments.

We measured the ${ }^{129} \mathrm{I} /{ }^{127} \mathrm{I}$ atom ratio in seawater samples collected near the wastewater pipeline outlet (St. 5) and these were reported elsewhere [6]. The ${ }^{129} \mathrm{I} /{ }^{127} \mathrm{I}$ atom ratios of $[2.0 \pm 1.5] \times 10^{-10}$ and $[0.49 \pm 0.22] \times 10^{-10}$ were found in the seawater samples collected during the cutting period and 2009 to 2010, respectively, with statistically significant differences between each other according to the $U$ test $(p<0.01)$. Although the data after 2010 were available, those were possibly affected by ${ }^{129}$ I released from the Fukushima Dai-ichi Nuclear Power Plant accident [5] and were excluded here. In addition, it should be noted that small scale discharge of ${ }^{129} \mathrm{I}(\sim 1 / 10$ of the maximum discharge rate

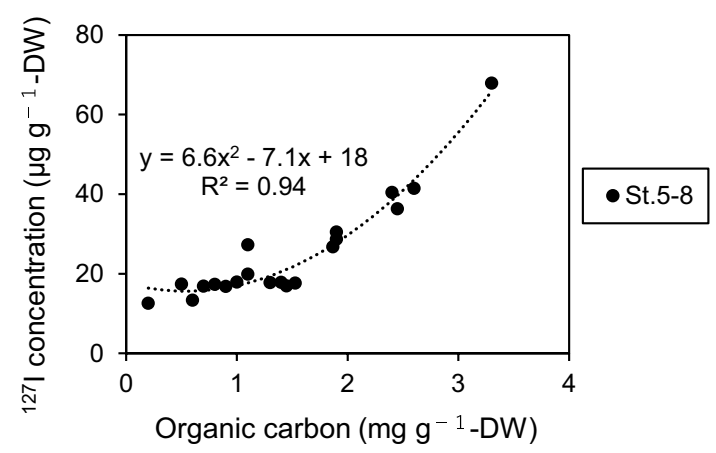

Fig. 3 Relationship between concentrations of stable iodine $\left({ }^{127} \mathrm{I}\right)$ and organic carbon in the offshore marine sediments

during the cutting period) continued during 2009 to 2010 (Fig. S1).

However, the ${ }^{129} \mathrm{I} /{ }^{127} \mathrm{I}$ atom ratios in offshore marine sediment samples were higher than the possible background ratio of $[0.49 \pm 0.22] \times 10^{-10}$ in seawater samples mentioned above. We have one background ${ }^{129} \mathrm{I} /{ }^{127} \mathrm{I}$ atom ratio in the seawater sample collected at St. 5 in 2005 (before cutting period) showing $0.50 \times 10^{-10}$ which was comparable to the values during 2009 to 2010 . Therefore, the ${ }^{129} \mathrm{I} /{ }^{127} \mathrm{I}$ atom ratio in offshore marine sediment samples may be approximately three times higher than that in the background seawater sample, although the ratio in the sediment samples is comparable to those in seawater at St. 5 during the cutting period. As mentioned above, even though the ${ }^{129} \mathrm{I} /{ }^{127} \mathrm{I}$ atom ratio in seawater samples during the cutting period was comparable with those in the marine sediment samples, it is not plausible that the ${ }^{129} \mathrm{I}$ in seawater affected the sediment, because there is no dilution effect of the ${ }^{129} \mathrm{I} /{ }^{127} \mathrm{I}$ atom ratios in the sediments with distance from the wastewater pipeline outlet of the reprocessing plant.

The ${ }^{129} \mathrm{I}$ concentration in the offshore marine sediment samples showed some variation with sampling location and date. The concentration of stable iodine $\left({ }^{127} \mathrm{I}\right)$ in the sediment samples is plotted against that of OC in Fig. 3. It is apparent from the figure, that the ${ }^{127} \mathrm{I}$ concentration clearly depends on the OC concentration. The dependence with OC is slightly observed in the ${ }^{129} \mathrm{I}$ concentration also (Fig. S2). The relationship of ${ }^{127} \mathrm{I}$ concentration against OC concentration appeared to be quadratic rather than linear. Regardless of the specific function, it is strongly suggested that ${ }^{127} \mathrm{I}$ in the sediment is bound to organic materials. Previous studies have also reported that the majority of iodine in the seabed sediments and terrestrial soils was combined with organic matter [10-15]. If terrestrial organic iodine compounds existed and accounted for a significant part of the sedimentary iodine, the higher ${ }^{129} \mathrm{I} /{ }^{127} \mathrm{I}$ atom ratio in the sediment compared to that in the seawater may be caused by sedimentation of terrestrial organic iodine compounds. 
Usui et al. [16] reported the stable isotope ratios of $\mathrm{C}$ and $\mathrm{N}$ and $\mathrm{C} / \mathrm{N}$ ratios in sediment samples in the continental shelf area around the river mouth of Tokachi River, Hokkaido, northeast Japan. They estimated the contribution of terrestrial organic materials to the marine sediment accounted for up to $50 \%$, depending on the direction and distance from the river mouth. The most affected sediment samples were collected in an area shallower than $100 \mathrm{~m}$ in depth, while the contributions to the area deeper than $100 \mathrm{~m}$ depth were small. Although there is no data for ${ }^{129} \mathrm{I} /{ }^{127} \mathrm{I}$ in organic materials in fresh water in the Rokkasho area, we reported the ${ }^{129} \mathrm{I} /{ }^{127} \mathrm{I}$ ratio of $[22 \pm 19] \times 10^{-10}$ ( 2 samples) for total iodine in water samples collected during 2005 from the Futamata River, which flows into Lake Obuchi. If we assume $22 \times 10^{-10}$ and $0.50 \times 10^{-10}$ as the ${ }^{129} \mathrm{I} /{ }^{127} \mathrm{I}$ atom ratios in terrestrial and marine organic materials, respectively, the iodine in terrestrial organic materials would contribute $\sim 5 \%$ of that in the coastal sediments with $1.5 \times 10^{-10}$ of the ${ }^{129} \mathrm{I} /{ }^{127} \mathrm{I}$ atom ratio. However, the Futamata River is a small river with an annual mean flow rate of ca. $0.5 \mathrm{~m}^{3} \mathrm{~s}^{-1}$ as measured by Aomori Prefecture, and we do not have data for the ${ }^{129} \mathrm{I} /{ }^{127} \mathrm{I}$ atom ratios of the major rivers flowing into the target sea area, such as the Mabechi River with an annual mean flow rate of ca. $60 \mathrm{~m}^{3} \mathrm{~s}^{-1}$ (website of Water Information System, Ministry of Land, Infrastructure, Transport and Tourism, http://www1.river.go.jp, in Japanese). Further studies are required to clarify the cause of the higher ${ }^{129} \mathrm{I} /{ }^{127} \mathrm{I}$ ratios in the marine sediment samples.

The ${ }^{129} \mathrm{I}$ concentrations and ${ }^{129} \mathrm{I} /{ }^{127} \mathrm{I}$ atom ratios in the sediment samples at St. 4 were clearly affected by the ${ }^{129} \mathrm{I}$ discharged from the reprocessing plant. Figure 4 shows the temporal trend of the ${ }^{129} \mathrm{I} /{ }^{127} \mathrm{I}$ atom ratios in the all sediment samples together with the ratio in the lake surface $(0-5 \mathrm{~cm})$ sediment samples from Lake Obuchi reported previously [8]. The sampling points for the lake sediments are shown in Fig. 1. As shown in Fig. 4, the ${ }^{129} \mathrm{I} /{ }^{127} \mathrm{I}$ atom ratio in the lake sediment samples significantly increased in 2008 and

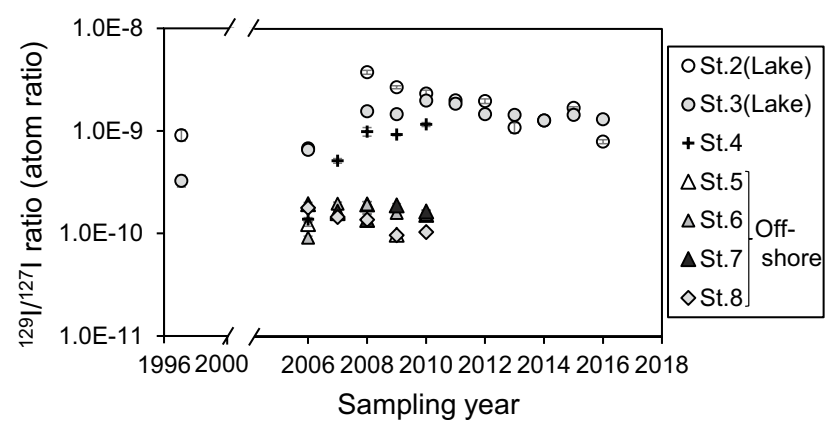

Fig. $4{ }^{129} \mathrm{I} /{ }^{127} \mathrm{I}$ atom ratios in sediment samples collected from the lake and ocean. The data for the lake surface $(0-5 \mathrm{~cm})$ sediments are from Ueda et al. [8]. The bars represent measurement errors described in Table 1 gradually decreased or remained fairly constant after the cutting period. The ${ }^{129}$ I inventories in the sediment samples up to $25 \mathrm{~cm}$ depth were reported to be almost constant after 2009 [8]. Unfortunately, the lake sediment samples were not collected in 2007. The ${ }^{129} \mathrm{I} /{ }^{127} \mathrm{I}$ atom ratio at St. 4 in 2006 was similar to values in the offshore marine sediments at St's. 5 to 8 , showing that ${ }^{129}$ I supplied from the lake water to the sediments of St. 4 was diluted by iodine in seawater in that year. The salinity in the water at St. 4 varied from 30 to $34 \mathrm{psu}$, while that in Obuchi Lake varied from 15 to $30 \mathrm{psu}$, supporting the dilution effect by seawater at St. 4. In 2007, the ${ }^{129} \mathrm{I} /{ }^{127} \mathrm{I}$ atom ratio at St. 4 started to increase and reached almost a half of that at the center of Lake Obuchi in 2010. Those results suggest that the ${ }^{129} \mathrm{I}$ in sediments in Obuchi Lake and at St. 4 may have originated from river water and/ or direct deposition to the lake water surface.

The ${ }^{137} \mathrm{Cs}$ concentrations in the sediment samples are shown in Table 1. Since no ${ }^{137} \mathrm{Cs}$ release from the reprocessing plant has been reported, the observed ${ }^{137} \mathrm{Cs}$ is considered to have originated from nuclear weapons fallout. According to the database of monitoring results around nuclear facilities in Japan (https://search.kankyo-hoshano.go.jp), maintained by Nuclear Regulation Agency, the ${ }^{137}$ Cs concentrations in coastal marine surface sediment samples $(n=198)$ collected during 2005 to 2010 around the nuclear facilities in Aomori Prefecture varied from below the detection limit $(n=82)$ to $5.3 \mathrm{~Bq} \mathrm{~kg}^{-1} \mathrm{DW}$ with a median value of $2.0 \mathrm{~Bq} \mathrm{~kg}^{-1}$-DW. The present ${ }^{137} \mathrm{Cs}$ concentrations are comparable to those values, but lower than the median.

The ${ }^{129} \mathrm{I} /{ }^{137} \mathrm{Cs}$ activity ratios in the present sediment samples were plotted in Fig. 5, together with those in the surface $(0-5 \mathrm{~cm})$ sediments in Lake Obuchi in 1997 [8, 17]. As with the ${ }^{129} \mathrm{I} /{ }^{127} \mathrm{I}$ atom ratios, the ${ }^{129} \mathrm{I} /{ }^{137} \mathrm{Cs}$ activity ratios in the marine sediment samples (St's 5 to 8 ) were fairly constant during the observation period and revealed no obvious effect on the ${ }^{129}$ I concentrations in those samples. Additionally, these values are comparable with those of the lake sediments

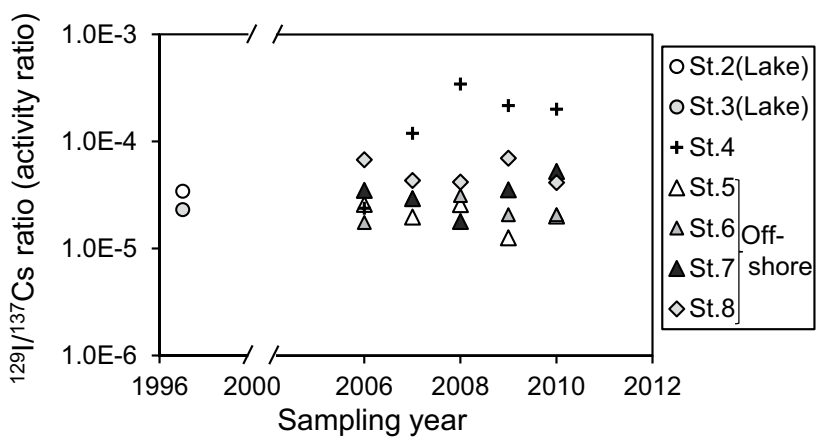

Fig. $5{ }^{129} \mathrm{I} /{ }^{137} \mathrm{Cs}$ activity ratios in sediment samples collected from the lake and ocean. The data for the lake is only available for 1997. The data for the lake surface $(0-5 \mathrm{~cm})$ sediments are from Ueda et al. $[8,14]$ 
before the cutting period. The ${ }^{129} \mathrm{I} /{ }^{137} \mathrm{Cs}$ activity ratios at St. 4 increased in 2007 and remained high after that year. This may suggest that ${ }^{129} \mathrm{I} /{ }^{137} \mathrm{Cs}$ activity ratio became an indicator of environmental radioactivity derived from the reprocessing plant in aquatic sediments.

\section{Conclusions}

The reprocessing plant at Rokkasho, Japan, carried out its test operation using actual spent fuel and discharged a controlled amount of ${ }^{129}$ I into the atmosphere and the Pacific Ocean. The bulk of the ${ }^{129}$ I was released to the ocean during 2006 to 2008. To assess the effect of this discharge of ${ }^{129} \mathrm{I}$ to marine sediments, we collected surface sediment samples at four offshore stations off the east coast of Aomori, Japan, with an additional station at Obuchi Fishing Port by the mouth of Lake Obuchi, every year from 2006 to 2010. Similar ${ }^{129} \mathrm{I} /{ }^{127} \mathrm{I}$ atom ratios were found in the offshore sediment samples throughout the observation period with no significant variation among the sampling stations. Since no data had been obtained in the target sea area before the test operation, we cannot directly compare the present results to the background. Since no obvious variation in the ${ }^{129} \mathrm{I} /{ }^{127} \mathrm{I}$ atom ratios was shown to be dependent on the discharge rate from the plant or distance from the wastewater pipeline outlet, our results strongly suggest that the discharged ${ }^{129} \mathrm{I}$ did not affect the ${ }^{129} \mathrm{I}$ levels in the offshore sediments. On the other hand, the ${ }^{129} \mathrm{I} /{ }^{127} \mathrm{I}$ atom ratios in the sediment samples at Obuchi Fishing Port clearly increased from 2007, showing that the ${ }^{129}$ I migrated from Lake Obuchi.

Acknowledgements The authors wish to thank the late Dr. Kunio Kondo, Institute for Environmental Sciences, for supporting the sampling. This work was performed under contract with the government of Aomori Prefecture, Japan.

Open Access This article is distributed under the terms of the Creative Commons Attribution 4.0 International License (http://creativeco mmons.org/licenses/by/4.0/), which permits unrestricted use, distribution, and reproduction in any medium, provided you give appropriate credit to the original author(s) and the source, provide a link to the Creative Commons license, and indicate if changes were made.

\section{References}

1. United Nations Scientific Committee on the Effects of Atomic Radiation (2008) UNSCEAR-2008 report, vol 2, Annex E (Effects of ionizing radiation on non-human biota)

2. United Nations Scientific Committee on the Effects of Atomic Radiation (2013) UNSCEAR-2013 report, vol 1, Annex A (Levels and effects of radiation exposure due to the nuclear accident after the 2011 great east-Japan earthquake and tsunami)

3. Snyder G, Aldahan A, Possnert G (2010) Global distribution and long-term fate of anthropogenic ${ }^{129} \mathrm{I}$ in marine and surface water reservoirs. Geochem Geophys Geosyst 11:1-19

4. Hou X, Povinec PP, Zhang L, Shi K, Biddulph D, Chang CC, Fan Y, Jeskovsky M, Liu Q, Steier P, Zhou W, Hou Y, Golser R (2013) Iodine-129 in seawater offshore Fukushima: distribution, inorganic speciation, sources, and budget. Environ Sci Technol 47:3091-3098

5. Otosaka S, Satoh Y, Suzuki T, Kuwabara J, Nakanishi T (2018) Distribution and fate of ${ }^{129} \mathrm{I}$ in the seabed sediment off Fukushima. J Environ Radioact 192:208-218

6. Ueda S, Kakiuchi H, Hasegawa H, Akata N, Kawamura H, Hisamatsu S (2015) Iodine-129 in water samples collected adjacent to a spent nuclear fuel reprocessing plant in Rokkasho, Japan. J Radioanal Nucl Chem 303:1211-1215

7. Ueda S, Kakiuchi H, Hasegawa N, Kawamura H, Hisamatsu S (2015) Concentration of ${ }^{129} \mathrm{I}$ in aquatic biota collected from a lake adjacent to the spent nuclear fuel reprocessing plant in Rokkasho, Japan. Radiat Prot Dosim 167:176-180

8. Ueda S, Kakiuchi H, Hisamatsu S (2018) Inventory of ${ }^{129}$ I in brackish lake sediments adjacent to a spent nuclear fuel reprocessing plant in Japan. J Radioanal Nucl Chem 318:89-96

9. Katano N, Mizutori M, Nakashiki N, Wada A (1989) Prediction model of oceanic diffusion for effluent from nuclear fuel reprocessing plant. Abiko Research Laboratory report no U88070 (in Japanese)

10. Harvey GR (1980) A study of the chemistry of iodine and bromine in marine sediments. Mar Chem 8:327-332

11. Francois R (1987) The influence of humic substances on the geochemistry of iodine in nearshore and hemipelagic marine sediments. Geochim Cosmochim Acta 51:2417-2427

12. Schlegel ML, Reiller P, Mercier-Bion F, Barre N, Moulin V (2006) Molecular environment of iodine in naturally iodinated humic substances: insight from X-ray absorption spectroscopy. Geochim Cosmochim Acta 70:5536-5551

13. Smyth D, Johnson CC (2011) Distribution of iodine in soils of Northern Ireland. Geochem Explor Environ Anal 11:25-39

14. Yamazaki S, Takeda A, Watanabe Y, Tagami K, Uchida S, Takata H, Mamejima Y, Kihou N, Tsuchiya N (2015) Bromine and iodine in Japanese soils determined with polarizing energy dispersive X-ray fluorescence spectrometry. Soil Sci Plant Nutr 61:751-760

15. Takeda A, Nakao N, Yamasaki S, Tsuchiya N (2018) Distribution and speciation of bromine and iodine in volcanic ash soil profiles. Soil Sci Soc Am J 82:815-825

16. Usui T, Nagao S, Yamamoto M, Suzuki K, Kudo I, Montani S, Noda A, Minagawa M (2006) Distribution and sources of organic matter in surficial sediments on the shelf and slope off Tokachi, western North Pacific, inferred from $\mathrm{C}$ and $\mathrm{N}$ stable isotopes and C/N ratios. Mar Chem 98:241-259

17. Ueda S, Ohtsuka Y, Kondo K (2004) Inventories of ${ }^{239+240} \mathrm{Pu}$, ${ }^{137} \mathrm{Cs}$, and excess ${ }^{210} \mathrm{~Pb}$ in sediment cores from brackish Lake Obuchi, Rokkasho Village, Japan. J Radioanal Nucl Chem 261:277-282

Publisher's Note Springer Nature remains neutral with regard to jurisdictional claims in published maps and institutional affiliations. 